\title{
Changes in the physicochemical and microbiological properties of probiotic-fermented low-fat yoghurt enriched with barley $\beta$-glucan during cold storage
}

\author{
Rafaat Mohamed Elsanhoty', Mohamed Fawzy Ramadan²,3
}

\footnotetext{
'Sadat City University, Department of Industrial Biotechnology, Institute of Genetic Engineering and Biotechnology, Egypt ${ }^{2}$ Zagazig University, Faculty of Agriculture, Department of Agricultural Biochemistry, Zagazig 44519, Egypt

${ }^{3}$ Umm Al-Qura University, Deanship of Scientific Research, Makkah, Saudi Arabia

*Corresponding author/Dopisni autor: Fax: +2 055 2287567;

Tel: +2 01229782424; E-mail: hassanienmohamed@yahoo.com
}

\section{Abstract}

This study aimed to investigate the quality attributes of probiotic-fermented low-fat yoghurt enriched with barley $\beta$-glucan $(B \beta G)$ during cold storage $\left(5{ }^{\circ} \mathrm{C}\right)$ for 21 days. Low-fat yoghurt formulation was based on substitution of fat in the skim milk (SM) with B $\beta G(0.75 \%$, w/v). Four formulations of yoghurt were prepared. The control formulation (without the addition of $B \beta G$ ) was produced from full cream bovine milk and fermented by yoghurt starter (YS). The first treatment (YS) was produced from SM without $B \beta G$ and fermented by YS. The second treatment was produced from SM with the addition of $B \beta G$ and fermented by YS (YSB $\beta G$ ). The third treatment was produced from SM without B $\beta G$ and fermented by Bifidobacterium lactis Bb-12, and Lactobacillus acidophilus LA-5 (PY). The fourth treatment was produced from SM with the addition of $0.75 \%$ B BG and fermented by Bifidobacterium lactis, and L. acidophilus (PYBBG). All samples were evaluated for their chemical composition, microbiological properties, the viability of probiotic microorganisms, sensory quality attributes during the storage period. The results indicated that addition of BBG improved the survival of probiotic bacteria and YS culture during storage period wherein the B $\beta G$-enriched yoghurt had high viable count. There were no significant differences $(p \leq 0.05)$ between the treatments in the microbiological quality and chemical composition. On the other hand, the addition of B BG improved the formation of flavor compounds in yoghurt. The substitution of fat with B $B G$ significantly $(p \leq 0.05)$ enhanced sensory attributes of yoghurt, wherein B $\beta G$-enriched samples recorded high score and acceptability. The lactic bacteria count was

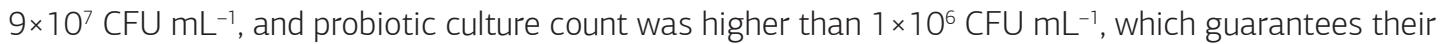
effect and ability to survive in the digestive tract and spread in the intestine. It could be concluded that substitution of fat with $B \beta G$ is a sufficient delivery truck of probiotic culture and B $B G$ could be used safely in functional dairy products.

Key words: dairy products, fat replacer, microbiological quality, sensory evaluation, Bifidobacterium lactis, Lactobacillus acidophilus 


\section{Introduction}

There is an increased interest and popularity of functional foods due to the growing awareness and demand of consumers. Fortification of food products with $\beta$-glucan ( $\beta G$ ) as a functional bioactive ingredient, is of great interest. $\beta$-glucans comprise a group of $\beta$-D-glucose polysaccharides naturally found in cell walls of cereals, yeast, bacteria, and fungi, with different properties dependent on the source (Gangopadhyay et al., 2015). Food and Drug Administration (FDA) has approved BG (3 g/ day) to treat coronary heart disease (FDA, 2005). $\beta$-D-glucose ( $\beta D G$ ) is poorly utilized in the human digestion tract and acts therefore as a non-caloric food which can be used in foods as a thickener, water retention, oil bending agent and an emulsion stabilizer (Satrapai et al., 2007; Santipanichwong and Suphantharika, 2009; Ferreira et al., 2010; Shen et al., 2010; Mahrous et al., 2014; Hassan et al., 2015). Some investigations have been focused on fortifying foods with $\beta G$ including pasta or tea cakes (Aman et al., 2004), muffins (Tosh et al., 2010), bread (Moriarety et al., 2010), and beverages (Wood, 2007; Marsh et al., 2014).

Yoghurt consumption has been steadily increased over the past years. The per capita consumption of yoghurt is expected to rise until the year 2020 ( $\mathrm{Sin}$ gh et al., 2012; Ahmed et al., 2017). There has been a great interest in the fortification of yoghurt with bioactive compounds to improve its nutritional value and benefits to health. Many studies have reported the influence of different ingredients like skim milk (SM) powder (Rohm and Schmidt, 1993), pectin, raspberry and blueberry concentrate (Fagan et al., 2006; Boycheva et al., 2011; Han et al., 2012), gum acacia (Fagan et al., 2006; Hassan et al., 2015), guar gum (Brennan and Tudorica, 2008), protein (Guzman-Gonzalez et al., 1999; Abdel-Haleem and Awad, 2015), gelatin (Fiszman et al., 1999; Soheil et al., 2010), k-carrageenan (Xu et al., 1992), calcium (Aportela-Palacios et al., 2005; Coskun and Senoglu, 2011), inulin (Guven et al., 2005; Fagan et al., 2006; Brennan and Tudorica, 2008; Balthazar et al., 2015; Glibowski and Rybak, 2016), and fiber (Elsanhoty et al., 2009; Ozcan and Kurtuldu, 2014; Ibrahim and Khalifa, 2015; Sah et al., 2016) on the function properties of dairy products and probiotic yoghurt. $\beta$-glucan ( $\beta G$ ) use in food is interesting, especially in yoghurt. Yet, there are limited reports on the fortification of yoghurt with barely $\beta$-glucan $(B \beta G)$. Being a widely spread food, low-fat yoghurt enriched with $\beta G$ might be helpful for many people suffering from diseases. It is well known that the amount and the type of fat consumed are important to the etiology of several chronic diseases, such as obesity, cardiovascular diseases and cancer (Shen et al., 2010; Gangopadhyay et al., 2015). Sahan et al. (2008) studied the effects of adding $\beta G$ to yoghurt but they used very low levels of $\beta G$ (0.05\%) from a $\beta G$ hydrocolloidal composite. Va siljevic et al. (2007) studied the growth and metabolic activity of probiotic organisms in $\beta G$-enriched yoghurt and reported that the addition of oat $\beta G$ resulted in improved probiotic viability and stability. Brennan and Tudorica (2008) found that $\beta G$ $(0.5 \%)$ addition improved serum retention and viscoelastic nature of yoghurt.

Milk fat plays an important role in the texture, flavor and color development of dairy products. Fat reduction can cause some defects in yoghurt and non-fat ice creams such as lack of flavor, weak body and poor texture (Huyghebaert et al., 1996). Although the manufacture of low-or non-fat dairy products was carried out for many years, the use of fat replacers in the manufacture of dairy products is still novel. Fat replacers, which decrease the calorific value of food, can be used to solve some physical and organoleptic problems originating from low-fat levels in the final products. Huyghebaert et al. (1996) indicated that fat replacers consist of mixtures of lipid originated fat substitutes, protein or carbohydrate originated fat mimetic, or their combinations.

To the best of our knowledge, there is no information about the addition of $B \beta G$ as a fat substitute on the quality attributes of low fat yoghurt. The hypothesis of this work was that substitution of fat with $B \beta G$ could deliver a truck of probiotic culture and BBG could be utilized safely in functional dairy products. The goal of this investigation was to study the quality attributes of probiotic-fermented low-fat yoghurt enriched with $B \beta G$ during cold storage at $5^{\circ} \mathrm{C}$. 


\section{Materials and methods}

\section{Materials}

Spray-dried SM powder (Type low heat, grade A) was obtained from the local market (Cairo, Egypt). Hoodlum hull-less barley was obtained from the Institute of Field Crop Research (Agricultural Research Centre, Giza, Egypt).

\section{Extraction of barley $\beta$-glucan (BBG)}

BRG was extracted from barely flour according to Benito-Román et al. (2011) with some modifications. Hull-less barley flour (HBF) was weighted in an Erlenmeyer flask, then water was added where liquid to solid ratio was 10:1 (v/w) and $\mathrm{pH}$ of the water was 6. Erlenmeyer flask was transferred to a water bath and incubated for $3 \mathrm{~h}$ at $55^{\circ} \mathrm{C}$. Then the flour was suspended at a high stirring rate. After the extraction, the separated mass was centrifuged at $5500 \mathrm{rpm}\left(4^{\circ} \mathrm{C}\right)$ for $10 \mathrm{~min}$. $\beta G$ was extracted from the clear supernatant after adjusting the concentration with ethyl alcohol (30\%) and keeping the mixture overnight at $5{ }^{\circ} \mathrm{C}$ wherein $\beta G$ was precipitated. The precipitate was freeze-dried using freeze-drier (Christ BETA 2-16, Osterode/Harz, Germany). The final product was packed in a plastic container and keep at $-20^{\circ} \mathrm{C}$.

\section{Bacterial strains and culture preparation}

Yoghurt cultures Streptococcus salivarius subsp. thermophilus, and L. delbrueckii sub sp. bulgaricus were obtained from the Egyptian Microbial Culture Collection (EMCC, Cairo Microbiological Resources Centre, Faculty of Agriculture, Ain Shams University, Egypt). Bifidobacterium lactis, and L. acidophilus LA-5 (freeze-dried red-set) were obtained from Chr. Hansen laboratories (Copenhagen, Denmark). Strains were cultured on deMan, Rogosa and Sharpe (MRS, Difico Laboratories) agar plates. Anaerobic strains were kept in an anaerobic jar (Anaerogen, Oxoid). Fully grown colonies were stored on plates at $4{ }^{\circ} \mathrm{C}$ with sub-culturing monthly. For long-term conservation of strains, spore or cell suspensions were kept in cryvials at $-80{ }^{\circ} \mathrm{C}$ with $90 \%$ glycerol as cryoprotectant. Lactobacilli were cultivated in MRS broth and bifidobacteria were grown in MRS broth with some supplementation with cysteine and incubated for $24 \mathrm{~h}$ at the suitable growth temperature. An appropriate volume of culture was used to inoculate $150 \mathrm{~mL}$ cultures and incubated for $24 \mathrm{~h}$ at $37^{\circ} \mathrm{C}$ in an anaerobic jar (Anaerogen, Oxoid). The working culture was prepared by adding a few milligrams the subculture to 100 $\mathrm{mL}$ of previously reconstituted and sterile $\left(121^{\circ} \mathrm{C} /\right.$ 2 min) SM with $10 \%$ total solids. This mixture was incubated at $42{ }^{\circ} \mathrm{C}$ until the onset of gelatin. Two $\mathrm{mL}$ of culture from this passage were transferred into $100 \mathrm{~mL}$ of sterile $\mathrm{SM}$ at $42^{\circ} \mathrm{C}$, and once again, the culture was incubated until a gel had formed. This second culture was used for the propagation of a bulk culture $(1 \mathrm{~L})$ for inoculation of the different treatments. Bulk cultures were prepared $24 \mathrm{~h}$ before the production of yoghurt.

\section{Preparation of yoghurt}

Preliminary studies were carried out to select the suitable amount of the freeze-dried $B \beta C$ that can be used in the production of low fat set-style yoghurt. Different amounts (0.25, 0.5, 0.75 and $1 \%)$ of B $\beta G$ were incorporated in the yoghurt formulation as a fat replacer. The yoghurt samples were sensory evaluated and the results indicated that the 0.75 $\%$ B $B G$ had the highest score. Based on this primary study, $0.75 \%$ B BG was used in the production of low-fat yoghurt in our investigation.

Fresh raw cow's milk was obtained from the Dinah Company (Giza, Egypt) and the yoghurt was produced as a control sample according to Singh et al. (2012). To adjust the solid content in the yoghurt milk to $14 \%$ (w/w), SM powder was used. The control treatment was produced from full cream milk without the addition of $B \beta G$ and fermented by a yoghurt starter (YS). Four replicate trials were conducted in the manufacture of yoghurt with low-fat milk (0.1\%) and whole fat milk (3.1\%) as a control. SM was prepared by separating whole milk using a cream separator (MCSE500, China) at $40^{\circ} \mathrm{C}$. Experimental groups were divided into four portions. The first portion was pasteurized at $80{ }^{\circ} \mathrm{C}$ for $15 \mathrm{~min}$ and cooled to $47^{\circ} \mathrm{C}$, inoculated with $3 \%(v / v)$ Streptococcus thermophilus, and Lactobacillius delbrueckii sub sp. bulgaricus (treatment I). The second portion was pasteurized at $80{ }^{\circ} \mathrm{C}$ for 15 min and cooled while SM was blended with $0.75 \%$ (w/v) B B , and the mixtures was homogenized with an Ultra Turrax blender (IKA, Merck, Germany) at 14000 rpm until all 
ingredients were dissolved in milk. The homogenate was inoculated with $3 \%(v / v)$ Streptococcus thermophilus, and Lactobacillius dulbrueekii subsp. bulgaricus (treatment II). The third portion was pasteurized at $80^{\circ} \mathrm{C}$ for 15 min and cooled to $47^{\circ} \mathrm{C}$, inoculated with Bifidobacterium lactis Bb-12, Lactobacillus acidophilus LA-5 probiotic YS (treatment III). The forth portion was pasteurized at $80^{\circ} \mathrm{C}$ for 15 min and cooled while SM was blended with $0.75 \% \mathrm{~B} \beta \mathrm{G}$, and the mixtures was homogenized until all ingredients were dissolved in the milk. The homogenate was inoculated with $3 \%$ Bifidobacterium lactis, and L. acidophilus probiotic YS (treatment IV). Yoghurt samples were dispersed into plastic cups (150 g), and incubated at $43^{\circ} \mathrm{C}$. All samples were kept at room temperature $\left(21^{\circ} \mathrm{C}\right)$ for 30 min then stored at $5^{\circ} \mathrm{C}$ for 21 days. Samples were withdrawn after $4,7,15$, and 21 days of storage for analysis.

\section{Microbiological analysis}

The total bacterial count (TBC) was determined according to Houghtby et al. (1992). Yeasts, molds and coliforms were enumerated according to the standard procedure (Marshall, 1992). Yoghurt cups were wiped from the outside with $70 \%$ ethanol and their contents were thoroughly mixed with a sterile spatula. A composite subsample was prepared by transferring yoghurt into a sterile $250 \mathrm{~mL}$ Erlenmeyer flask that contained sterile phosphate buffer and blended with warm buffer $\left(40^{\circ} \mathrm{C}\right)$ until a homogeneous mixture was obtained. TBC and coliform were determined by the pour plate technique, while yeasts and molds were enumerated by the spread plate technique. TBC was determined using plate count agar and incubation was for $48 \mathrm{~h}$ at $32{ }^{\circ} \mathrm{C}$. Coliform was enumerated on violet red bile agar after incubation at $37^{\circ} \mathrm{C}$ for $24 \mathrm{~h}$. Yeasts and molds were enumerated on plate count agar that contained $0.01 \%$ chloramphenicol and $0.01 \%$ chlortetracycline hydrochloride and incubated at $25^{\circ} \mathrm{C}$ for 5 days, and at $5^{\circ} \mathrm{C}$ for 10 days, respectively.

Streptococcus thermophilus was enumerated using of M17 agar according to Ravula and Shah, (1998), L. delbrueckii subsp. bulgaricus was enumerated according to Van de Casteele et al. (2006) using of MRS agar.

Enumeration and viability of Bifidobacterium lactis and L. acidophilus. Bifidobacterium lactis, and L. acidophilus were determined in MRS-OG mixture solution of $0.02 \%$ Oxgall and $0.03 \%$ Gentamince according to Lim et al. (1995). Plates were incubated an aerobically at $37^{\circ} \mathrm{C}$ for 48 h. L. acidophilus was determined using lactobacillus selective agar plus 0.2 Oxgell (LBSO) (Gilliland and Walker, 1990). The plates were incubated at $37^{\circ} \mathrm{C}$ for 4 days.

\section{Chemical analysis}

Total solid, protein, fat, lactose and ash content of yoghurt were determined according to AOAC (2000). Total titratable acidity (TTA) determined by titrating $10 \mathrm{~g}$ of sample with $0.1 \mathrm{~N} \mathrm{NaOH}$ using phenolphthalein indicator. $\mathrm{pH}$ values of yoghurt samples were recorded using digital $\mathrm{pH}$ meter (model SA 720, Orion, USA). Acetaldehyde was determined according to Lees and Jago (1969) using Conway micro-diffusion-Semicarbazide method. Acetaldehyde reacts with the semicarbazide to form semicarbazone which has an absorption peak at $224 \mathrm{~nm}$. The earlier procedure was followed to determine diacetyl content at $270 \mathrm{~nm}$ as described by Lees and Jago (1976). Organic acids were determined using high performance liquid chromatography (HPLC). HPLC, from Waters Associates equipped with 600E multi-solvent delivery system and millennium chromatography workstation, was used. The determination was carried out at wave

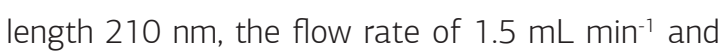
ambient temperature, Altec column (250x4.6 mm) with mobile phase $0.001 \% \mathrm{H}_{2} \mathrm{SO}_{4}$, were applied. The sample $(3 \mathrm{~g})$ was mixed with $7 \mathrm{~mL}$ of buffer mobile phase, homogenized (vortex for $1 \mathrm{~min}$ ), extracted for $1 \mathrm{~h}$ and centrifuged at 7000xg for 5 min. The supernatant was filtered through $0.45 \mu \mathrm{m}$ membrane filter (Sartorious SM 11606) then $20 \mu \mathrm{L}$ were injected with $25 \mu \mathrm{L}$ Hamilton syringe (Hamilton Co., Reno, NV). HPLC grade reagents were used as standards (Sigma, St. Louis, MO, USA). Twenty microliters of each membrane filtered $(0.22 \mu \mathrm{m})$ sample were injected using M6k manual injector at ambient temperature equilibrated with mobile phase at flow rate of $1.5 \mathrm{~mL} \mathrm{~min}{ }^{-1}$. The absorbed organic acids (formic, pyruvic, lactic, acetic and citric) were eluted isocratically using the mobile phase $0.001 \mathrm{H}_{2} \mathrm{SO}_{4}(1 \mathrm{LMQ}$ water added to $1 \mathrm{~mL}$ sulfuric acid). Five organic acid standards were dissolved in HPLC water with known concentrations and $20 \mu \mathrm{L}$ were injected under the same conditions. Organic 
acids were quantified by comparison of peak areas of authentic samples with those of the corresponding organic acid standard solution using the millennium Data System Program. All analyses of yoghurt samples were done in triplicates.

\section{Sensory evaluation}

All yoghurt samples were stored at $0,4,7,15$ and 21 days at $5{ }^{\circ} \mathrm{C}$ and evaluated for flavor, texture, appearance and overall acceptability by 20 of staff members from Dairy Technology Department (Agricultural Research Center) and Institute of Genetic Engineering and Biotechnology (Agricultural Research Center) who are familiar with yoghurt sensory characteristics. A nine-point hedonic scale (Stone and Sidel, 1985) was utilized in this study (9 $=$ like extremely, 5 = neither like nor dislike, and $1=$ extreme dislike).

\section{Statistical analysis}

Statistical analysis was performed by running Student t-test using Stat view 512 software (1986). Chi-square was performed to compare between the controls and experimental yoghurt. Significant effects were declared $p<0.05$.

\section{Results and discussion}

\section{Microbiological properties}

The viability and survival of probiotic bacteria are important parameters for assessing the product quality. Figure 1 presents the effect of adding $B \beta G$ on the viability of Bifidobacterium lactis in yoghurt during 21 days of storage at $5{ }^{\circ} \mathrm{C}$. The results showed that there was an increase in the log count of Bifidobacterium lactis in treatments with Bifidobacterium lactis and L. acidophilus enriched with $\mathrm{B} \beta \mathrm{G}$, reaching the highest count after 4 days of storage. Thereafter, a gradual decrease in the count was observed for all treatments during the storage period. The bifidobacterial counts remained above the therapeutic level of $10^{7} \mathrm{CFU} / \mathrm{g}$ over the 21 days of storage for B $\beta G$ treatments. However, even though Bifidobacterium lactis survival was time-dependent, average counts remained considerably above the therapeutic threshold, indi- cating that time dependency was not of practical significance. The results are in full concord with the results obtained by Vasiljevic et al. (2007); Elsanhoty et al. (2009); Arena et al. (2014) who attributed the decrease in the viability of Bifidobacterium lactis to their sensitivity towards low $\mathrm{pH}$ arising mainly from the high concentrate of lactic and acetic acids (Saccaro et al., 2011). Moreover, probiotic yoghurt with $B \beta G$ had higher viable counts compared to other treatments. The present results are also in complete harmony with those obtained by other workers who demonstrated that addition of $B \beta G$ enhanced the growth and survival of probiotic bacteria (Vasiljevic et al., 2007; Elsanhoty et al., 2009). The obtained results are also in agreement with Mousa and Abd El-Gawad (2007) who reported that the incorporation of synbiotics (Dairy-Lo and 0.1 Dairy Loid) improved the growth and survival of probiotic bacteria in labneh. Generally, there were better growth and survival of probiotic bacteria in the products supplemented with B $\beta G$. A further support is obtained from similar findings of other researchers who reported that the Bifidobacterium are relatively sensitive to low $\mathrm{pH}$. The results are also in agreement with Chou and Hou (2002); Laine et al. (2003) and Rosburg et al. (2010) who reported that the Bifidobacterium can grow and reduce the $\mathrm{pH}$ of the oat-based medium. It could be concluded that addition of B $\beta$ G had a protective effect on bifidobacteria in yoghurt when stressed by low-temperature storage.

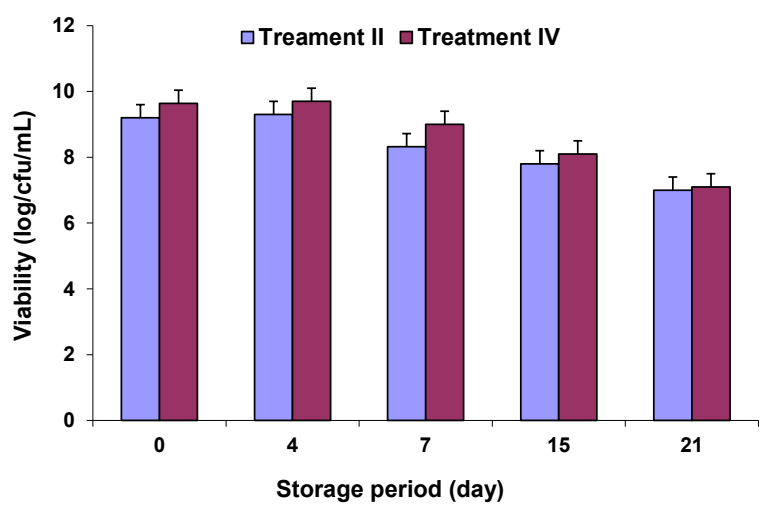

Treatment II =Yoghurt starter with $0.75 \%$ BBG (YSBBG) Treatment IV= Probiotic yoghurt starter with $0.75 \%$ B $\beta G$ (PYSBBG)

FIGURE 1. Effect of adding BßG on the viability (log/cfu/mL) of Bifidobacterium lactis in yoghurt during storage 


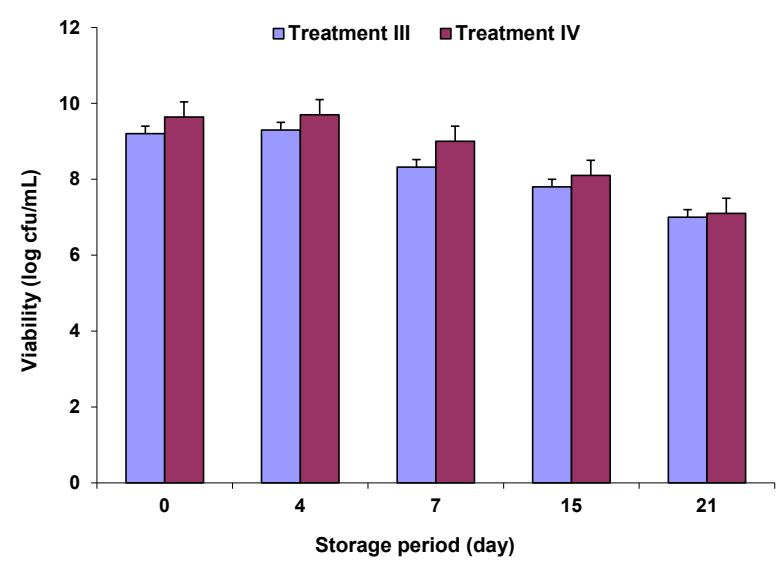

Treatment III= Probiotic yoghurt starter (PYS) Treatment IV= Probiotic yoghurt starter with $0.75 \%$ BBC (PYSBBG)

FIGURE 2. Effect of adding B $\beta G$ on the viability ( $\log / \mathrm{cfu} / \mathrm{mL})$ of L. acidophilus in yoghurt during storage

Data in Figure 2 present the effect of BBG enrichment on the viability of $L$. acidophilus in yoghurt during storage. The log count of treatment III which produced without B $B G$ was nearly similar to the log count of treatment IV that formulated with adding BßG. There were no significant differences $(p<0.05)$ between treatment III and treatment IV in the viability of $L$. acidophilus. The data indicated that there were gradual decreases in the count for all treatments during the storage period. L. acidophilus remained nearly the therapeutic level of $10^{7} \mathrm{CFU} / \mathrm{mL}$ at the end of 21 days of storage in BBG-enriched samples. From the obtained data, it could be concluded that the addition of BBG improved the viability of $L$. acidophilus. Similar results were reported by other researchers concerning the viability and survival of $L$. acidophilus and other lactobacilli in oat mash (Charalampopoulos et al., 2002; Angelov et al., 2006; Akalin et al., 2012; Elsanhoty et al., 2009; Champagne et al., 2011). The growth in BBG substrate was also similar to those reported in oat substrates inoculated L. plantarum (Angelov et al., 2006; Mahrous et al., 2014). In addition, similar results were obtained by Phuapaiboon et al. (2013) who reported that the addition of pineapple to yoghurt enhanced the probiotic viability during 28 days of storage.

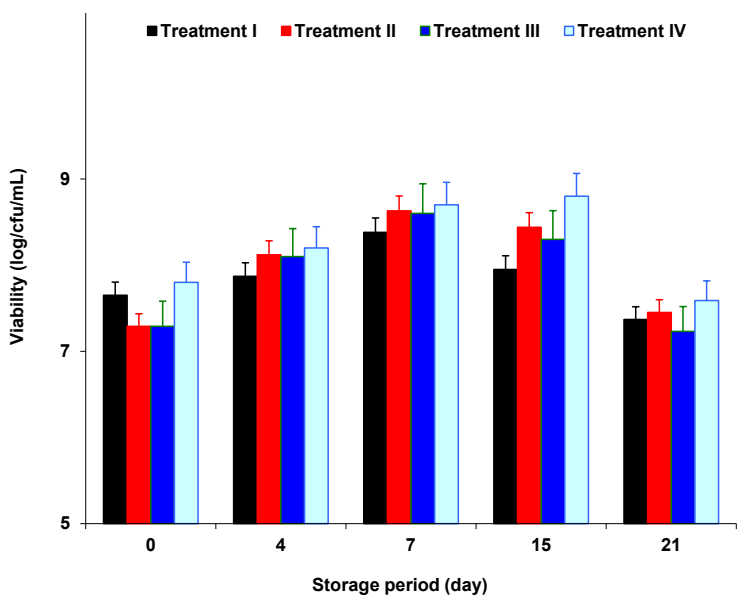

Treatment $I=$ Yoghurt starter (YS)

Treatment II =Yoghurt starter with $0.75 \%$ BBG (YSBBG)

Treatment III= Probiotic yoghurt starter (PYS)

Treatment IV= Probiotic yoghurt starter with $0.75 \%$ BßG (PYSBBG)

FIGURE 3. Effect of adding of BBG on the total microbial counts $(\mathrm{log} / \mathrm{cfu} / \mathrm{mL})$ in yoghurt during storage

Figure 3 presents the total microbial counts in all yoghurt treatments during storage period at 5 ${ }^{\circ} \mathrm{C}$. Results indicated that there was gradual increase by increasing the storage period reached the highest level after 7 days of storage, and then decreased. The total microbial count changes of a stirred yoghurt showed the same trend of Bifidobacterium lactis growth as shown in Figure 1, which represented most of the microflora found in yoghurt beside other microorganisms that resisted the heat treatment. In addition, the results showed that the addition of $B \beta G$ to milk had no effect on the total microbial counts, since all treatments recorded total microbial counts similar to control. The highest total microbial count was recorded in control treatment. The total microbial count was slightly increased during the storage period. At the end of storage, yoghurt samples containing $B \beta G$ had the highest total microbial counts. Similar results were obtained by Zare and Orsat (2012); Digbabul et al. (2014) and Mahrous et al. (2014) who found that the addition of probiotics to yoghurt has no changes in viable cell counts during storage for 28 days. 
TABLE 1. Changes in yeasts and molds count $(\log 10)$ of yoghurt during storage

\begin{tabular}{l|l|l|l|l|l}
\hline \multirow{2}{*}{ Treatment } & \multicolumn{5}{l}{ Storage period (day) } \\
\cline { 2 - 7 } & 0 & 4 & 7 & 15 & 21 \\
\hline Control & 1.25 & 2.19 & 3.44 & 4.71 & 6.98 \\
\hline I - Yoghurt starter (YS) & 1.24 & 2.21 & 3.55 & 4.87 & 6.2 \\
\hline $\begin{array}{l}\text { II - Yoghurt starter with 0.75 \% BBG } \\
\text { (YSBBG) }\end{array}$ & 1.44 & 2.3 & 3.71 & 4.81 & 7.83 \\
\hline III - Probiotic yoghurt starter (PYS) & 1.63 & 2.11 & 3.45 & 4.91 & 6.91 \\
\hline $\begin{array}{l}\text { IV - Probiotic yoghurt starter with 0.75 \% } \\
\text { BBG (PYSBBG) }\end{array}$ & 1.71 & 2.33 & 3.97 & 5.1 & 8.97 \\
\hline
\end{tabular}

All yoghurt samples contained coliforms $<1.0$ CFU/g during the storage period. In this work, all yoghurt samples showed a significant increase in yeast and mold counts whereas the initial yeast and mold count were high in B $\beta G$-enriched yoghurt (Table 1). Similar results were reported by Tamine and Robinson (2004) and Ifeanyi et al. (2013) who found that initial counts of yeast and mold were not more than $1 \mathrm{CFU} / \mathrm{mL}$, but when storage time get longer the yeast and mold counts increased. Similar results were also obtained by Elsanhoty et al. (2009), Gohnamy et al. (2009), and Mahrous et al. (2014) who stated that the coliforms were not detected all over storage period in yoghurt at the beginning and at the end of the storage periods.

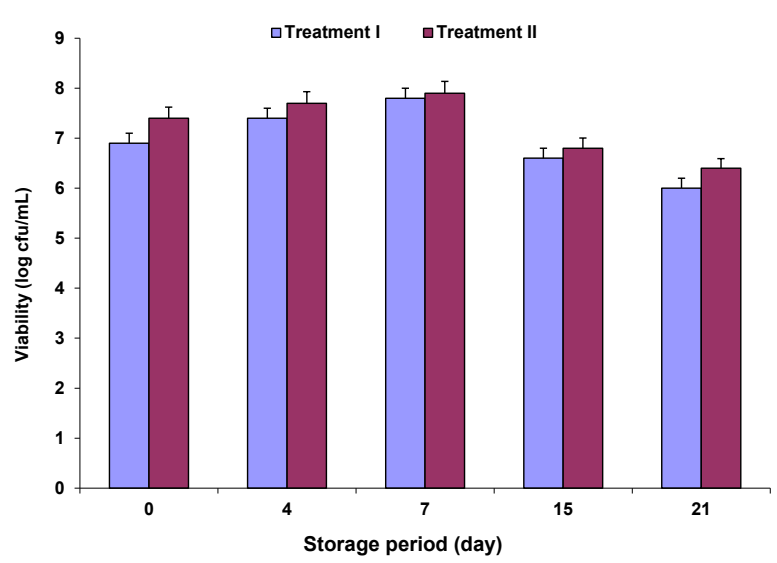

Treatment I = Yoghurt starter (YS)

Treatment II =Yoghurt starter with 0.75\% BßG (YSBBG)

FIGURE 4. Effect of adding BßG on the viability (log/cfu/mL) of mixed yoghurt cultures (S. thermophilus and L. bulgaricus) in yoghurt during storage
Figure 4 shows the viability of yoghurt cultures S. thermophilus and L. bulgaricus in yoghurt containing bifidobacteria, L. acidophilus and B $\beta$ G. The date in this figure indicated that there was an increase in the number of $\mathrm{S}$. thermophilus and $\mathrm{L}$. bulgaricus during storage period until reach the highest level then decreased after 7 days of storage. The mixed yoghurt cultures (S. thermophilus and L. bulgaricus) survived at a level of the level of $10^{6} \mathrm{CFU} / \mathrm{mL}$. The high survival of yoghurt cultures was consistent with studies indicating that $S$. thermophilus and $L$. bulgaricus strains survived well during cold storage at low pH (Dave and Shah, 1997; Saccaro et al., 2011). The data also suggest an effect of time on average cell counts wherein the cell count decrease slightly by decreasing of storage time. The obtained results agreed with Vasiljevic et al. (2007); Elsanhoty et al. (2009); Ashraf and Shah (2011); Arena et al. (2014) and Salmerón et al. (2015) who reported that the addition of prebiotics improved the survival of the probiotic bacteria and culture microorganisms due to high fermentability of $B \beta G$ by microorganisms.

\section{Chemical composition}

Table 2 presents the chemical composition of different yoghurt formulations. The total solids (TS) content of samples ranged from $11.98 \%$ to $12.13 \%$, the protein content ranged from $3.00 \%$ to $3.12 \%$. In general, the obtained values of chemical composition agree with values reported by Dublin-Green and Ibe (2005). The addition of BBG and usage of probiotic bacteria in the production of yoghurt had no significant effect on the levels of protein, TS, lactose, and ash in different formualtions. The obtained results were agreement with Gohnamy et al. (2009); Has- 
sanein et al. (2008); Elsanhoty et al. (2009) and Mahrous et al. (2014) who reported that the addi- tion of $B \beta G$ and oat $\beta G$ has no effect on the chemical composition of stirred yoghurt and labneh.

TABLE 2. Composition of different yoghurt samples

\begin{tabular}{|c|c|c|c|c|c|}
\hline Treatment & $\begin{array}{l}\text { Total } \\
\text { solids (\%) }\end{array}$ & Lipids (\%) & Protein (\%) & Lactose (\%) & Ash (\%) \\
\hline Control & $14.3 \pm 1.4$ & $3.1 \pm 0.4$ & $3.31 \pm 0.3$ & $3.75 \pm 0.2$ & $1.09 \pm 0.1$ \\
\hline I -Yoghurt starter (YS) & $12.3 \pm 1.2$ & ND & $3.12 \pm 0.4$ & $3.70 \pm 0.1$ & $0.98 \pm 0.2$ \\
\hline II -Yoghurt starter with $0.75 \%$ BßG (YSB & $12.11 \pm 1.6$ & ND & $3.11 \pm 0.1$ & $3.80 \pm 0.2$ & $0.99 \pm 0.1$ \\
\hline III- Probiotic yoghurt starter (PYS) & $11.98 \pm 1.3$ & ND & $3.00 \pm 0.2$ & $3.6 \pm 0.2$ & $0.98 \pm 0.0$ \\
\hline $\begin{array}{l}\text { IV- Probiotic yoghurt starter with } 0.75 \% \\
\text { B } \beta \text { G (PYSB } \beta \text { G) }\end{array}$ & $12.21 \pm 1.1$ & ND & $3.11 \pm 0.3$ & $3.9 \pm 0.3$ & $1.01 \pm 0.1$ \\
\hline
\end{tabular}

$\mathrm{ND}=$ not determined

TABLE 3. Changes in $\mathrm{pH}$ of yoghurt during storage

\begin{tabular}{|c|c|c|c|c|c|}
\hline \multirow[t]{2}{*}{ Treatment } & \multicolumn{5}{|c|}{ Storage period (day) } \\
\hline & 0 & 4 & 7 & 15 & 21 \\
\hline Control & $4.21 \pm 0.4$ & $4.09 \pm 0.3$ & $3.94 \pm 0.7$ & $3.88 \pm 0.5$ & $3.80 \pm 0.4$ \\
\hline I -Yoghurt starter (YS) & $4.23 \pm 0.5$ & $4.11 \pm 0.6$ & $3.99 \pm 0.6$ & $3.89 \pm 1.2$ & $3.83 \pm 0.6$ \\
\hline II -Yoghurt starter with 0.75\% BßG (YSB $3 G)$ & $4.31 \pm 0.3$ & $4.02 \pm 0.5$ & $3.88 \pm 0.7$ & $3.81 \pm 0.9$ & $3.75 \pm 0.7$ \\
\hline III- Probiotic yoghurt starter (PYS) & $4.50 \pm 0.9$ & $4.44 \pm 0.4$ & $4.33 \pm 0.8$ & $4.29 \pm 0.7$ & $3.99 \pm 0.3$ \\
\hline $\begin{array}{l}\text { IV- Probiotic yoghurt starter with } 0.75 \% \\
\text { B } \beta \text { G (PYSB } \beta \text { ) }\end{array}$ & $4.17 \pm 0.8$ & $3.97 \pm 0.3$ & $3.88 \pm 0.7$ & $3.84 \pm 0.5$ & $3.82 \pm 0.7$ \\
\hline
\end{tabular}

Data are presented as means $\pm \operatorname{SDM}(n=3)$

Data in Table 3 represented the changes of $\mathrm{pH}$ in yoghurt during storage period at $5{ }^{\circ} \mathrm{C}$. Results indicated that the lowest value of $\mathrm{pH}$ was 4.17 and the highest value was 4.5. There was an increase in the $\mathrm{pH}$ values during storage periods to rich the values from 3.81 to 3.99. Data indicated that there was a little decrease in the $\mathrm{pH}$ values in the formulations contained $\mathrm{B} \beta \mathrm{G}$. The obtained results agreed with the results obtained by Gee et al. (2007) and Mahrous et al. (2014) who reported that addition of high concentrated $B \beta G$ had no significant effect on the ability of the starter cultures to ferment. Our results indicated that $\mathrm{pH}$ of yoghurt supplemented with $\mathrm{B} \beta \mathrm{C}$ tended to be lower than before addition. The obtained results were in disagreements with Sahan et al. (2008) who reported that the use of $\beta G$ hydrocollidal composite in the manufacture of low-fat yoghurt did not significantly influence $\mathrm{pH}$, titratable acidity, acetaldehyde, volatile fatty acid and tyrosine levels at any storage time. Prasanna et al. (2013) and Sah et al. (2016) also observed similar pH changes during refrigerated storage of yoghurt-type products and probiotic yoghurt fortified with fiber-rich pineapple peel powder during cold storage.

TABLE 4. Changes in TTA of yoghurt samples during storage

\begin{tabular}{|c|c|c|c|c|c|}
\hline \multirow[t]{2}{*}{ Treatment } & \multicolumn{5}{|c|}{ Storage period (day) } \\
\hline & 0 & 4 & 7 & 15 & 21 \\
\hline Control & $0.76 \pm 0.1$ & $0.81 \pm 0.2$ & $0.85 \pm 0.1$ & $0.92 \pm 0.2$ & $1.2 \pm 0.4$ \\
\hline I - Yoghurt starter (YS) & $0.72 \pm 0.1$ & $0.80 \pm 0.2$ & $0.83 \pm 0.1$ & $0.91 \pm 0.2$ & $1.18 \pm 0.3$ \\
\hline $\begin{array}{l}\text { II - Yoghurt starter with } 0.75 \% \text { B } \\
\text { (YSB } 3 \text { ) }\end{array}$ & $0.90 \pm 0.3$ & $0.94 \pm 0.5$ & $1.2 \pm 0.2$ & $1.38 \pm 0.2$ & $1.43 \pm 0.7$ \\
\hline III - Probiotic yoghurt starter (PYS) & $0.85 \pm 0.2$ & $0.95 \pm 0.1$ & $1.09 \pm 0.1$ & $1.21 \pm 0.3$ & $1.23 \pm 0.3$ \\
\hline $\begin{array}{l}\text { IV - Probiotic yoghurt starter with } 0.75 \% \\
\text { BßG (PYSB } \beta G)\end{array}$ & $0.91 \pm 0.1$ & $1.1 \pm 0.2$ & $1.21 \pm 0.2$ & $1.25 \pm 0.3$ & $1.48 \pm 0.3$ \\
\hline
\end{tabular}

Data are presented as means \pm SD $(n=3)$ 
Total titratable acidity (TTA) changes in low fat yoghurt during cold storage are presented in Table 4. The results showed that TTA gradually increased throughout the storage period and recorded the highest level at the end of storage. The results indicated that BBG-enriched formulations contained higher TTA than other treatments, while control sample contained the lowest TTA during cold storage. These results confirmed the $\mathrm{pH}$ values (Table 3) and both L. acidophilus and bifidobacteria counts in Figures 1, 2 and 4. The increase in the lactic acid bacteria counts might be due to decreasing the $\mathrm{pH}$ values and increasing TTA. Similar results were obtained by Dello Staffolo et al. (2004); Elsanhoty et al. (2009); Akalın et al. (2012) and Mahrous et al. (2014). Our finding is in contrast with Vinderola et al. (2000) who observed no significant changes in $\mathrm{pH}$ of probiotic yoghurt made with B. bifidum. One reason for these differences could be the fact that the drop in $\mathrm{pH}$ is mainly due to the activity of the yoghurt starters rather than the bifidobacteria.

The volatile compounds in yoghurt play an important role for the consumer acceptance. These volatile metabolites are known as major aroma compounds of yoghurt (Cheng, 2010). Acetaldehyde is the most important compound contributing to typical yoghurt aroma, which is mainly generated by threonine metabolism by yoghurt starters. The most important compounds produced by lactic starter cultures are acetaldehyde, diacetyl, acetone, acetic acid and lactic acid. The balance between them is thought to determine the yoghurt acceptability. In this study, acetaldehyde and diacetyl were determined. Data in Table 5 indicated that there were differences between the treatments $(p<0.05)$ and slight impact of B $\beta G$ on the levels of acetaldehyde. The values of acetaldehyde and diacetyl were arranged from 3.34 to $3.99 \mathrm{mg} / \mathrm{kg}$ for acetaldehyde and from 6.21 to 7.11 for diacetyl at the end of storage period. In our study, the levels of acetaldehyde and diacetyl were decreased with time of storage. Similar findings were observed in the manufacture of maize porridge with malted barley, yoghurt with barley flour, labneh with BßG and yoghurt with oat $\beta G$ (Helland et al., 2004; Elsanhoty et al., 2009; Mahrous et al., 2014). The decrease in acetaldehyde opens a new way for their conversions to ethanol via the action of alcohol dehydrogenase (Tamime and Robinson, 2001). These results were in accordance with those reported by Serra et al. (2009) and Salmerón et al. (2015).

TABLE 5. Changes in acetaldehyde and diacetyl concentrations of yoghurt samples during storage

\begin{tabular}{|c|c|c|c|c|c|}
\hline \multirow[t]{3}{*}{ Treatment } & \multicolumn{5}{|c|}{ Acetaldehyde } \\
\hline & \multicolumn{5}{|c|}{ Storage period (day) } \\
\hline & 0 & 4 & 7 & 15 & 21 \\
\hline Control & $5.61 \pm 0.1$ & $5.39 \pm 0.1$ & $4.31 \pm 0.4$ & $4.12 \pm 0.1$ & $3.91 \pm 0.1$ \\
\hline I - Yoghurt starter (YS) & $5.59 \pm 0.2$ & $5.38 \pm 0.4$ & $4.27 \pm 0.1$ & $4.1 \pm 0.2$ & $3.92 \pm 0.2$ \\
\hline $\begin{array}{l}\text { II - Yoghurt starter with } 0.75 \% \text { B } 3 G \\
\text { (YSBBG) }\end{array}$ & $5.81 \pm 0.4$ & $4.43 \pm 0.1$ & $4.14 \pm 0.3$ & $3.99 \pm 01$ & $3.34 \pm 0.4$ \\
\hline III - Probiotic yoghurt starter (PYS) & $5.82 \pm 0.9$ & $4.95 \pm 0.2$ & $4.36 \pm 0.1$ & $4.11 \pm 0.1$ & $3.99 \pm 0.3$ \\
\hline $\begin{array}{l}\text { IV - Probiotic yoghurt starter with } 0.75 \% \\
\text { BßG (PYSBßG) }\end{array}$ & $5.89 \pm 0.1$ & $5.29 \pm 0.3$ & $4.44 \pm 0.1$ & $4.1 \pm 0.1$ & $3.65 \pm 0.1$ \\
\hline \multirow[t]{3}{*}{ Treatment } & \multicolumn{5}{|l|}{ Diacetyl } \\
\hline & \multicolumn{5}{|c|}{ Storage period (day) } \\
\hline & 0 & 4 & 7 & 15 & 21 \\
\hline Control & $11.65 \pm 1.9$ & $10.93 \pm 1$ & $9.91 \pm 1.1$ & $8.41 \pm 0.8$ & $7.12 \pm 0.5$ \\
\hline I - Yoghurt starter (YS) & $11.70 \pm 1.2$ & $10.86 \pm 0.9$ & $9.93 \pm 0.9$ & $8.42 \pm 0.5$ & $7.11 \pm 0.3$ \\
\hline $\begin{array}{l}\text { II - Yoghurt starter with } 0.75 \% \text { B } \\
\text { (YSB } B \text { ) }\end{array}$ & $11.90 \pm 1.3$ & $10.14 \pm 1$ & $9.89 \pm 1.2$ & $7.85 \pm 1.1$ & $6.78 \pm 0.7$ \\
\hline III - Probiotic yoghurt starter (PYS) & $10.63 \pm 1.6$ & $9.87 \pm .1 .1$ & $8.83 \pm 0.9$ & $7.10 \pm 1$ & $6.21 \pm 1.1$ \\
\hline $\begin{array}{l}\text { IV - Probiotic yoghurt starter with } 0.75 \% \\
\text { BBG (PYSBßG) }\end{array}$ & $11.36 \pm 1.7$ & $10.39 \pm 1.1$ & $8.99 \pm 1.1$ & $8.2 \pm 0.8$ & $6.85 \pm 0.6$ \\
\hline
\end{tabular}


The organic acids in fermented dairy foods are indicators of the metabolic activity of added bacterial cultures. These acids act as natural preservatives and contribute to the characteristic sensory properties. Data in Table 6 presents the organic acid's profile in different yoghurt treatments during storage. In fresh samples, lactic acid was detected and determined in all treatments but there was increase in lactic acid in the treatments I and II. This means that the addition of B $B G$ supported the development of lactic acid. There was also an increase in the lactic acid and acetic acid production throughout the storage period. The production of pyruvic and formic acids was detected after 15 days of storage in all samples, but increased when B $\beta G$ was added. The obtained results agreed with Adhikari, et al. (2002), Volikakis et al. (2004), Elsanhoty et al. (2009), Başyiğit Kılıç and Akpınar (2013) and Salmerón et al. (2015).

TABLE 6. Changes in levels of organics acids in yoghurt samples during storage

\begin{tabular}{|c|c|c|c|c|c|}
\hline \multirow[t]{2}{*}{ Treatment } & \multirow{2}{*}{$\begin{array}{l}\text { Storage } \\
\text { period (day) }\end{array}$} & \multicolumn{4}{|c|}{ Organic acid (mg/100 mL) } \\
\hline & & $\begin{array}{l}\text { Lactic } \\
\text { acid }\end{array}$ & Acetic acid & Formic acid & Pyruvic acid \\
\hline I-YS & \multirow{4}{*}{0} & 130.63 & 51.34 & $\mathrm{ND}^{\mathrm{a}}$ & ND \\
\hline II- YSBBG & & 149.11 & 56.67 & ND & ND \\
\hline III- PYS & & 160.12 & 53.81 & ND & ND \\
\hline IV- PYSBßG & & 161.32 & 71.13 & ND & ND \\
\hline I-YS & \multirow{4}{*}{4} & 131.81 & 51.98 & ND & ND \\
\hline II- YSBBG & & 151.12 & 53.76 & ND & ND \\
\hline III- PYS & & 164.19 & 52.21 & ND & ND \\
\hline IV- PYSBßG & & 166.34 & 66.77 & ND & ND \\
\hline I-YS & \multirow{4}{*}{7} & 135.23 & 52.85 & ND & ND \\
\hline II- YSBBG & & 156.16 & 55.54 & ND & ND \\
\hline III- PYS & & 166.56 & 54.71 & ND & ND \\
\hline IV- PYSBßG & & 169.15 & 63.18 & ND & ND \\
\hline I-YS & \multirow{4}{*}{15} & 138.78 & 54.11 & 24.76 & 19.70 \\
\hline II- YSBBG & & 159.23 & 57.12 & 26.78 & 22.43 \\
\hline III- PYS & & 168.67 & 57.71 & 37.16 & 36.43 \\
\hline IV- PYSBßG & & 171.60 & 68.97 & 34.86 & 38.32 \\
\hline I-YS & \multirow{4}{*}{21} & 148.78 & 52.12 & 32.86 & 29.76 \\
\hline II- YSBBG & & 164.98 & 51.41 & 34.84 & 28.98 \\
\hline III- PYS & & 177.97 & 53.52 & 42.64 & 40.29 \\
\hline IV- PYSBßG & & 188.98 & 62.66 & 44.24 & 46.53 \\
\hline
\end{tabular}

${ }^{\mathrm{a} N D}=$ not determined 
TABLE 7. Effect of adding BBG on organoleptic properties of yoghurt during storage

\begin{tabular}{|c|c|c|c|c|c|}
\hline Treatments & $\begin{array}{l}\text { Storage } \\
\text { period (day) }\end{array}$ & Flavor (50) & $\begin{array}{l}\text { Body and } \\
\text { texture } \\
(40)\end{array}$ & $\begin{array}{l}\text { Appearance } \\
\text { (10) }\end{array}$ & $\begin{array}{l}\text { Total } \\
(100)\end{array}$ \\
\hline \multirow[t]{5}{*}{ Control } & 0 & 42 & 36 & 9 & 87 \\
\hline & 4 & 43 & 35 & 9 & 87 \\
\hline & 7 & 43 & 35 & 9 & 87 \\
\hline & 15 & 43 & 37 & 9 & 89 \\
\hline & 21 & 44 & 37 & 8 & 89 \\
\hline \multirow[t]{5}{*}{ I - Yoghurt starter (YS) } & 0 & 42 & 35 & 9 & 86 \\
\hline & 4 & 42 & 35 & 9 & 86 \\
\hline & 7 & 43 & 35 & 9 & 87 \\
\hline & 15 & 43 & 37 & 9 & 89 \\
\hline & 21 & 44 & 37 & 8 & 89 \\
\hline \multirow{5}{*}{$\begin{array}{l}\text { II - Yoghurt starter with } 0.75 \% \\
\text { BßG (YSBBG) }\end{array}$} & 0 & 42 & 36 & 9 & 87 \\
\hline & 4 & 43 & 37 & 9 & 89 \\
\hline & 7 & 45 & 37 & 9 & 91 \\
\hline & 15 & 43 & 36 & 9 & 88 \\
\hline & 21 & 44 & 36 & 9 & 89 \\
\hline \multirow{5}{*}{$\begin{array}{l}\text { III - Probiotic yoghurt starter } \\
\text { (PYS) }\end{array}$} & 0 & 44 & 35 & 9 & 88 \\
\hline & 4 & 44 & 35 & 9 & 88 \\
\hline & 7 & 45 & 36 & 9 & 90 \\
\hline & 15 & 45 & 37 & 9 & 91 \\
\hline & 21 & 46 & 37 & 9 & 92 \\
\hline \multirow{5}{*}{ 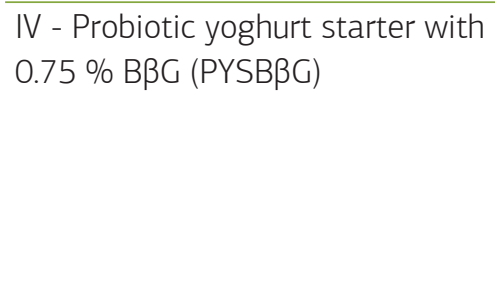 } & 0 & 46 & 35 & 9 & 90 \\
\hline & 4 & 44 & 36 & 9 & 89 \\
\hline & 7 & 44 & 37 & 9 & 90 \\
\hline & 15 & 43 & 37 & 9 & 89 \\
\hline & 21 & 44 & 36 & 9 & 89 \\
\hline
\end{tabular}

\section{Sensory evaluation}

Table 7 presents the effect of the addition of $B B G$ on the sensory characteristics of yoghurt during storage periods. In general, the addition of $B \beta G$ improved various characteristics of yoghurt in comparison to the control sample. The addition of B BG affected appearance, color, texture and overall preference, but no such effect was found for flavor. There were no differences in textural properties between treatments. The treatments with $B \beta G$ had higher appearance scores than other treatments. Different yoghurt formulations had a good quality and strong curd integrity without any sign of shrinkage, disintegration into lumps, and syneresys at the end of storage period. Similar results were obtained by Tuinier et al. (2000), Elsanhoty et al. (2009), Mahrous et al. (2014), and Salmerón et al. (2015). It could be said that the low-fat yoghurt enriched with BBG had good flavor, taste, texture and appearance among all treatments of yoghurt. 


\section{Conclusions}

Yoghurt consumption has been steadily increased over the past years. In the present study, yoghurt prepared with Bifidobacterium lactis, $L$. acidophilus, Streptococcus thermophilus and L. delbrueckii subsp. bulgaricus showed good compatibility with yoghurt starter culture. The addition of $B \beta G$ enhanced the viability of the probiotic strains in the fermented products during cold storage. Yoghurt samples containing $0.75 \%$ B $\beta$ G were acceptable to expert panelists and had scores similar to the control yoghurt sample. It could be concluded that substitution of fat in yoghurt with BßG was a sufficient delivery truck of the probiotic culture and B $B G$ could be safely used in functional dairy products.

\section{Promjene fizikalno-kemijskih i mikrobioloških parametara tijekom skladištenja niskomasnog probiotičkog jogurta obogaćenog $\beta$-glukanima iz zobi}

\section{Sažetak}

Cilj ovog rada bio je ispitati parametre kvalitete tijekom 21 . dana hladnog skladištenja $\left(5^{\circ} \mathrm{C}\right)$ probiotičkog niskomasnog jogurta obogaćenog $\beta$-glukanima iz zobi (BßG). Niskomasni jogurt proizveden je iz obranog mlijeka u prahu (SM) s dodatkom BßG (0,75 \%) kao zamjene za mast. Pripremljene su četiri različite serije jogurta. Kontrolni uzorak (bez dodatka BßG) pripremljen je od punomasnog kravljeg mlijeka koje je fermentirano klasičnom jogurtnom kulturom (YS). Prva serija jogurta proizvedena je od SM bez dodatka BßG koje je fermentirano jogurtnom kulturom YS. Druga serija jogurta proizvedena je od SM uz dodatak BßG koje je fermentirano jogurtnom kulturom YS (YSBßG). Treća serija jogurta proizvedena je od SM bez dodatka BßG koje je fermentirano probiotičkim sojevima Bifidobacterium lactis Bb-12 i Lactobacillus acidophilus LA-5 (PY). Četvrta serija jogurta proizvedena je od SM uz dodatak 0,75 \% BßG koje je fermentirano probiotičkim sojevima Bifidobacterium lactis, i L. acidophilus (PYBßG). Svim uzorcima su tijekom perioda skladištenja određivani kemijski sastav, mikrobiološka kvaliteta, broj živih stanica probiotičkih bakterija i senzorska svojstva. Dobiveni rezultati su pokazali da je dodatak BßG poboljšao preživljavanje probiotičkih bakterija, kao i bakterija u sastavu jogurtne kulture. Nisu uočene značajnije razlike $(p \leq 0,05)$ u mikrobiološkoj kvaliteti i kemijskom sastavu proizvedenih serija jogurta. Međutim, dodatak B $\beta G$ poboljšao je tvorbu arome u jogurtima. Zamjena masti dodatkom BßG značajno $(p \leq 0,05)$ je poboljšala senzorska svojstva jogurta koji su imali veće ocjene i prihvatljivost. Broj živih stanica bakterija mliječne kiseline kretao se oko $9 \times 10^{7} \mathrm{CFU} \mathrm{mL}{ }^{-1}$, dok je broj živih stanica probiotičkih bakterija bio iznad probiotičkog minimuma od $1 \times 10^{6} \mathrm{CFU} \mathrm{mL} \mathrm{mL}^{-1}$. Iz svega navedenog može se zaključiti da je zamjena mliječne masti s BßG uspješan način osiguravanja preživljavanja probiotičkih bakterija te se može sigurno primjenjivati u proizvodnji funkcionalnih mliječnih proizvoda.

\section{Ključne riječi: mliječni proizvodi, zamjena za mast, mikrobiološka kvaliteta, senzorska ocjena, Bifidobacterium lactis, Lactobacillus acidophilus}

\section{Conflict of interest statement}

No conflicts of interest exist in this study.

\section{References}

1. Abdel-Haleem, M.H.A., Awad, A.R. (2015): Some quality attributes of low fat ice cream substituted with hulless barley flour and barley $\beta$-glucan. Journal of Food Science and Technology 52, 6425-6434.

https://doi.org/10.1007/s13197-015-1755-x
2. Adhikari, K., Grun, I.U., Mustapha, A., Fernando, L.N. (2002): Changes in the profile of organic acids in plain set and stirred yoghurts during manufacture and refrigerated storage. Journal of Food Quality 25, 435-451. https://doi.org/10.1111/j.1745-4557.2002.tb01038.x 
3. Ahmed, R.M., Elsanhoty, R.M., Al-Saman, M.A., Ramadan, M.F. (2017): Hypocholesterolaemic effect of probiotic yoghurt enriched with barley -glucan in rats fed on a high-cholesterol diet. Mediterranean Journal of Nutrition and Metabolism 10, 1-12. https://doi.org/10.3233/MNM-16114

4. Akalın, A.S., Unal, G., Dinkci, N., Hayaloglu, A.A. (2012): Microstructural, textural, and sensory characteristics of probiotic yoghurts fortified with sodium calcium caseinate or whey protein concentrate. Journal of Dairy Science 95, 3617-3628. https://doi.org/10.3168/jds.2011-5297

5. Aman, P., Rimsten, L., Andersson, R. (2004): Molecular weight distribution of $\beta$-glucan in oat-based foods. Cereal Chemistry 81, 356-60. https://doi.org/10.1094/CCHEM.2004.81.3.356

6. Angelov, A., Gotcheva, V., Kuncheva, R., Hrstozova, T. (2006): Development of a new oat-based probiotic drink. International Journal of Food Microbiology 112,75-80. https://doi.org/10.1016/j.ijfoodmicro.2006.05.015

7. AOAC International (2000): Official methods of analysis of AOAC International. $17^{\text {th }}$ edition. Gaithersburg, MD, USA, Association of Analytical Communities.

8. Aportela-Palacios, A., Sosa-Morales, M.E., Veluz-Ruiz, J.F. (2005): Rheolgical and physicochemical behavior of fortified yoghurt with fiber and calcium. Journal of Texture Studies 36, 333-49. https://doi.org/10.1111/j.1745-4603.2005.00020.x

9. Arena, P.M., Caggianiello, G., Fiocco, D., Russo, P., Torelli, M., Spano, G., Vittorio Capozzi, V. (2014): Barley $\beta$-Glucanscontaining food enhances probiotic performances of beneficial bacteria. International Journal Molecular Sciences 15, 3025-3039. https://doi.org/10.3390/ijms15023025

10. Ashraf, R., Shah, N.P. (2011) Selective and differential enumerations of Lactobacillus delbrueckii subsp. bulgaricus, Streptococcus thermophilus, Lactobacillus acidophilus, Lactobacillus casei and Bifidobacterium spp. in yoghurt-a review. International Journal of Food Microbiology 149, 194-208. https://doi.org/10.1016/j.ijfoodmicro.2011.07.008

11. Balthazar, C.F., Gaze, L.V., Azevedo da Silva, H.L., Pereira, C.S., Franco, R.M., Conte-Júnior, C.A., de Freitas, M.Q., de Oliveira Silva, A.C. (2015): Sensory evaluation of ovine milk yoghurt with inulin addition. International Journal Dairy Technology 68, 281-290. https://doi.org/10.1111/1471-0307.12189

12. Başyiğit Kılıç, G., Akpınar, D. (2013): The effects of different levels of $\beta$-glucan on yoghurt manufactured with Lactobacillus plantarum strains as adjunct culture. Journal of Food, Agriculture and Environment 11, 281-287.

13. Benito-Román, O., Alonso, E., Lucas, S. (2011): Optimization of the $\beta$-glucan extraction conditions from different waxy barley cultivars. Journal of Cereal Science 53, 271-276. https://doi.org/10.1016/j.jcs.2011.01.003

14. Boycheva, S., Dimitrov, T., Nikolina, T.N., Naydenova Mihaylova, G. (2011): Quality characteristics of yoghurt from goat's Milk, supplemented with fruit juice. Czech Journal of Food Science 1, 24-30. https://doi.org/10.17221/171/2008-CJFS

15. Brennnan, C.S., Tudorica, C.M. (2008): Carbohydrate-based fat replacers in the modification of the rheological, textural and sensory quality of yoghurt: comparative study of the utilisation of barley beta-glucan, guar gum and inulin. International Journal of Food Science and Technology 43, 824-33. https://doi.org/10.1111/j.1365-2621.2007.01522.x

16. Champagne, C.P., Ross, R.P., Saarela, M., Hansen, K.F., Charalampopoulos, D. (2011): Recommendations for the viability assessment of probiotics as concentrated cultures and in food matrices. International Journal of Food Microbiology 149, 185-193. https://doi.org/10.1016/j.jfoodmicro.2011.07.005

17. Charalampopoulos, D., Wang, R., Pandiella, S.S., Webb, C. (2002): Application of cereals and cereals components in functional foods: A review. International Journal of Food Microbiology 69, 131-141. https://doi.org/10.1016/S0168-1605(02)00187-3

18. Cheng, H. (2010): Volatile flavor compounds in yoghurt: a review. Critical Review in Food Science and Nutrition 50, 938-950. https://doi.org/10.1080/10408390903044081

19. Chou, C.C., Hou, J.W. (2002): Growth and survival of bifidobacteria and lactic acid bacteria during the fermentation and storage of cultured soymilk drinks. Food Microbiology 19, 501-508. https://doi.org/10.1006/fmic.2002.0506

20. Coskun, F., Senoglu, C. (2011): The effect of using different levels of calcium carbonate on the physical, chemical and sensory properties of yoghurt. GIDA The Journal of Food 36, 129-135.

21. Dello Staffolo, M., Bertola, N., Martino, M., Bavilacqua, A. (2004); Influence of dietary fiber addition on sensory and rheological properties of yoghurt. International Dairy Journal 14, 263-268. https://doi.org/10.1016/j.idairyj.2003.08.004

22. Digbabul, B., Shember, J., Amove, J. (2014): Physicochemical, microbiological and sensory evaluation of yoghurt sold in Makurdi metropolis. African Journal of Food Science and Technology 5, 129-135.

23. Dublin-Green, M., Ibe, S.N. (2005) Quality evaluation of yoghurts produced commercially in Lagos, Nigeria. African Journal of Applied Zoology and Environmental Biology 7. 78-82.

24. Elsanhoty, R., Zaghlol, A., Hassanein, A. (2009): The manufacture of low fat labneh containing barely betaGlucan 1-Chememical composition, microbiological evaluation and sensory properties. Current Research in Dairy Sciences 1, 1-12. https://doi.org/10.3923/crds.2009.1.12

25. Fagan, C.C., O’Donnell, C.P., Cullen, P.J., Brennan, C.S. (2006): The effect of dietary fiber inclusion on milk coagulation kinetics. Journal of Food Engineering 77, 261-268. https://doi.org/10.1016/j.jfoodeng.2005.06.030

26. Ferreira, I.M.P.L.V.O., Pinho, O., Vieira, E., Tavarela, J.G. (2010): Brewer's Saccharomyces yeast biomass: characteristics and potential applications. Trends in Food Science and Technology 21, 77-84. https://doi.org/10.1016/j.tifs.2009.10.008

27. Fiszman, D.M., Luch, M.A., Salvador, A. (1999): Effect of addition of gelatin on microstructure of acidic milk gels and yoghurt and on their rheological properties. International Dairy Journal 9:895-901. https://doi.org/10.1016/S0958-6946(00)00013-3 
28. Food and Drug Administration (FDA) (2005): Food labeling: health claims; oat and coronary heart disease; final rule federal register doc. 97-1598, filed 1-22-1997.

29. Gangopadhyay, N., Hossain, B.M., Rai, K.D., Brunton, P.N. (2015): A review of extraction and analysis of bioactives in oat and barley and scope for use of novel food processing technologies. Molecules 20, 10884-10909. https://doi.org/10.3390/molecules200610884

30. Gee, V.L., Vasanthan, T., Temelli, F. (2007): Viscosity of model yoghurt systems enriched with barley $\beta$-glucan as influenced by starter cultures. International Dairy Journal 17, 1083-1088. https://doi.org/10.1016/j.idairyj.2007.01.004

31. Ghonamy, A.G., Elsanhoty, R.M., Metwalli, S.A.H. (2009): Effect of skim milk powder substitution with barley flour on the properties of probiotic fruit flavored stirred yoghurt. Annals of Agriculture Science-Moshtohor 47, 93-104.

32. Gilliland, S.E., Walker, K. (1990): Factor to consider when selecting a culture of $\mathrm{Lb}$. acidophilus as a dietary adjunct to produce a hypocholesterolmic effect in humans. Journal of Dairy Science 73, 905-911. https://doi.org/10.3168/jds.S0022-0302(90)78747-4

33. Glibowski, P., Rybak, P. (2016): Rheological and sensory properties of stirred yoghurt with inulin-type fructans. International Journal of Dairy Technology 69, 122-128. https://doi.org/10.1111/1471-0307.12231

34. Guven, M., Yasar, K., Karaco, O.B., Hayalogu, A.A. (2005): The effect of inulin as a fat replacer on the quality of settype low-fat yoghurt manufacture. International Journal of Dairy Technology 58,180-184. https://doi.org/10.1111/j.1471-0307.2005.00210.x

35. Guzman-Gonzalez, M., Mercedes, F.M., Amigo, R.L. (1999): Influence of skimmed milk concentrate replacement by dry dairy products in a low set-type yoghurt system. I. Use of whey protein concentrate, milk protein concentrate and skimmed milk powder. Journal of The science of Food and Agriculture 79, 1117-1122.

https://doi.org/10.1002/(SICI)10970010(199906)79:8<1117::AID-JSFA335>3.0.CO;2-F

36. Han, X., Lee, L.F., Zhang, L., Guo, M.R. (2012): Chemical composition of water buffalo milk and its low-fat symbiotic yoghurt development. Functional Foods in Health and Disease 2, 86-106. https://doi.org/10.31989/ffhd.v2i4.96

37. Hassan, K.L., Haggag, H.F., ElKalyoubi, M.H., Abd EL-Aziz, M., ElSayed, M.M., Sayed, A.F. (2015): Physico-chemical properties of yoghurt containing cress seed mucilage or guar gum. Annals of Agricultural Sciences-Moshtohor Sci 60, 21-28. https://doi.org/10.1016/j.aoas.2014.11.021

38. Hassanein, A.M., Zaghloul, A.H., Elsanhoty, R.M. (2008): Effect of different bacterial strains on like-labneh products from buffaleo's milk and hull-less barley. Journal of Agriculture Sciences-Mansoura University 33, 5853-5864.

39. Helland, H.M., Wicklund, T., Narvhs, J.A. (2004): Growth and metabolism of selected strains of probiotic bacteria, in maize porridge with added malted barley. International Journal of Food Microbiology 91, 305-315. https://doi.org/10.1016/j.ijfoodmicro.2003.07.007

40. Houghtby, G.A., Maturin, L.J., Koening, E.K. (1992): Microbiological court methods. In: R.T. marshal (Ed). Standard methods for the examination of dairy products (16 ${ }^{\text {th }}$ ed.) pp. 213-246. American Public Health Association (APHA), Washington DC, USA.
41. Huyghebaert, A., Dewettinck, K., Greyt, W. (1996): Fat replacers. Bulletin of International Dairy Federation, Brussels, Belgium, 317, pp.10-15.

42. Ibrahim, A.H., Khalifa, S.A. (2015): Improve sensory quality and textural properties of fermented camel's milk by fortified with dietary fiber. Journal of American Science 11, 42-54.

43. Ifeanyi, V.O., Ihesiaba, E.O., Muomaife, O.M., Ikenga, C. (2013): Assessment of microbiological quality of yoghurt sold by Street Vendors in Onitsha Metropolis, Anambra State, Nigeria. British Microbiology Research Journal 3 , 198-205. https://doi.org/10.9734/BMRJ/2013/1801

44. Laine, R., Salminen, S., Benno, Y., Ouwehand, C.A. (2003): Performance of bifidobacteria in oat-based media. International Journal of Food Microbiology 83, 105-109. https://doi.org/10.1016/S0168-1605(02)00318-5

45. Lees, G.J., Jago, G.R. (1976): Formation of acetaldehyde from threonine by lactic acid. Journal of Dairy Research 43 , 75-83. https://doi.org/10.1017/S0022029900015612

46. Lees, G.J., Jago, G.R. (1969): Methods for estimation of acetaldehyde in cultured dairy products. Australian Journal of Dairy Technology 24, 181-185.

47. Lim, KS, Huh, C.S., Baek, Y.J., Kim, HU (1995): A selective enumeration medium for bifidobacterium in fermented Dairy products. Journal of Dairy Science 78, 2108-2112. https://doi.org/10.3168/jds.S0022-0302(95)76837-0

48. Mahrous, H., Kholy, W.M.E., Elsanhoty, R.M. (2014): Production of new synbiotic yoghurt with local probiotic isolate and oat and study its effect on mice. Advances in Dairy Research 2, 2.

49. Marsh, A.J., Colin Hill, R., Ross, P, Cotter, D.P. (2014): Fermented beverages with health-promoting potential: past and future perspectives. Trends in Food Science and Technology 38, 113-124. https://doi.org/10.1016/j.tifs.2014.05.002

50. Marshall, R.T. (1992): Standard methods for the examination of dairy products. American Public Health Association (APHA), Washington, DC, USA.

51. Mistry, V.V., Hassan, H.N. (1992): Manufacture of yoghurt stabilized with milk powder. Journal of Dairy Science 75, 947-957. https://doi.org/10.3168/jds.S0022-0302(92)77835-7

52. Moriarety, S., Temelli, F., Vasanthan, T. (2010): Effect of formulation and processing treatments on viscosity and solubility of extractable barley $\beta$-glucan in bread dough evaluated under in vitro conditions. Cereal Chemistry 87 , 65-72. https://doi.org/10.1094/CCHEM-87-1-0065

53. Ozcan, T., Kurtuldu, O. (2014): Influence of dietary fiber addition on the properties of probiotic yoghurt. International Journal of Chemical Engineering and Applications 5, 397-401. https://doi.org/10.7763/IJCEA.2014.V5.417

54. Phuapaiboon, P., Leenanon, B., Levin, R.E. (2013): Effect of Lactococcus lactis immobilized within pineapple and yam bean segments, and Jerusalem Artichoke powder on its viability and quality of Yoghurt. Food and Bioprocess Technology 6, 2751-2762. https://doi.org/10.1007/s11947-012-0940-4 
55. Prasanna, P.H.P., Grandison, A.S., Charalampopoulos, D. (2013): Microbiological, chemical and rheological properties of low fat set yoghurt produced with exopolysaccharide (EPS) producing Bifidobacterium strains. Food Research International 51, 15-22. https://doi.org/10.1016/j.foodres.2012.11.016

56. Ravula, R.R., Shah, N.P. (1998): Selective enumeration of Lactobacillus casei from yoghurt and fermented milk drinks. Biotechnology Techniques 12, 819-822. https://doi.org/10.1023/A:1008829004888

57. Rohm, H., Schmidt, W. (1993): Influence of dry matter fortification on flow properties of yoghurt I. Evaluation of flow curves. Michwissenschaft 48, 556-560

58. Rosburg, V., Boylston, T., White, P. (2010): Viability of Bifidobacteria strains in yoghurt with added oat betaglucan and corn starch during cold storage. Journal of Food Science $75,439-444$. https://doi.org/10.1111/j.1750-3841.2010.01620.x

59. Saccaro, D.M., Hirota, C.Y., Tamime, A.Y., De Oliveira, M.N. (2011): Evaluation of different selective media for enumeration of probiotic micro-organisms in combination with yoghurt starter cultures in fermented milk. African Journal of Microbiology Research 6, 2239-2245.

60. Sah, B.N.P., Vasiljevic, T., McKechnie, S., Donkor, O.N. (2016): Physicochemical, textural and rheological properties of probiotic yoghurt fortified with fibre-rich pineapple peel powder during refrigerated storage. LWT-Food Sci Technol 65, 978-986. https://doi.org/10.1016/j.lwt.2015.09.027

61. Sahan, N., Yasar, K., Hayaloglu, A.A. (2008): Physical, chemical and flavor quality of non-fat yoghurt as affected by a $\beta$-glucan hydrocolloidal composite during storage. Food Hydrocolloids 22:1291-1297. https://doi.org/10.1016/j.foodhyd.2007.06.010

62. Salmerón, I., Thomas, K., Pandiella, S.S. (2015): Effect of potentially probiotic lactic acid bacteriaon the physicochemical composition and acceptance of fermented cereal beverages. Journal of Functional Foods 15, 106-115. https://doi.org/10.1016/j.jff.2015.03.012

63. Santipanichwong, R., Suphantharika, M. (2009): Influence of different $\beta$-glucans on the physical and rheological properties of egg yolk stabilized oil-in-water emulsions. Food Hydrocolloids 23, 1279-1287. https://doi.org/10.1016/j.foodhyd.2008.10.006

64. Satrapai, S., Suphantharika, M. (2007): Influence of spent brewer's yeast $\beta$-glucan on gelatinization and retrogradation of rice starch. Carbohydrate Polymers 67 , 500-510. https://doi.org/10.1016/j.carbpol.2006.06.028

65. Serra, M., Trujillo, J.A., Guamis, B., Ferragut, V. (2009): Flavour profiles and survival of starter cultures of yoghurt produced from high-pressure homogenized milk. International Dairy Journal 19, 100-106. https://doi.org/10.1016/j.idairyj.2008.08.002

66. Shen, R., Shuangqun, L., Dong, J. (2010): Application of oat dextrin for fat substitute in mayonnaise. Food Chemistry 126, 65-71. https://doi.org/10.1016/j.foodchem.2010.10.072
67. Singh, M., Kim, S., Liu, X.S. (2012): Effect of purified Oat $\beta$-glucan on fermentation of set-style yoghurt mix. Journal of Food Science 77, 10514-10523. https://doi.org/10.1111/j.1750-3841.2012.02828.x

68. Soheil, A.A., Aelami, M., Rezaei, R. (2010): Influence of fleawort seed hydrocolloid on physicochemical and sensory characteristics of low-fat yoghurt. Iranian Food Science and Technology Research Journal 6, 201-209.

69. Stone, H., Sidel, J.L. (1985): Sensory Evaluation Practices. $1^{\text {st }}$ Edn, Academic Press, New York.

70. Tamime, A.Y., Robinson, R.K. (2001): Yoghurt Science and Technology. CRC Pres. New York, US.

71. Tosh, S.M., Brummer, Y., Miller, S.S., Regand, A., Defelice, C., Duss, R., Woelver, M.S., Wood, P.J. (2010): Processing affects the physicochemical properties of $\beta$-glucan in oat bran cereal. Journal of Agricultural and Food Chemistry 58, 7723-7730. https://doi.org/10.1021/jf904553u

72. Tuinier, R., Grotenhuis, T.E., de Kruif, C.G. (2000): The effect of depolymerised guar gum on the stability of skim milk. Food Hydrocolloids 14, 1-7. https://doi.org/10.1016/S0268-005X(99)00039-9

73. Van de Casteele, S., Vanheuverzwijn, T., Ruyssen, T., Van Assche, P., Swings, J., Huys, G. (2006): Evaluation of culture media for selective enumeration of probiotic strains of lactobacilli and bifidobacteria in combination with yoghurt or cheese starters. International Dairy Journal 16, 1470 1476. https://doi.org/10.1016/j.idairyj.2005.12.002

74. Vasiljevic, T., Kealy, T., Mishra, V.K. (2007): Effects of $\beta$-glucan addition to a probiotic containing yoghurt. Journal of Food Science 72, 405-411. https://doi.org/10.1111/j.1750-3841.2007.00454.x

75. Vinderola, C.G., Bailo, N., Reinheimer, J.A. (2000): Survival of probiotic microflora in Argentinian yoghurts during refrigerated storage. Food Research International 33, 97102. https://doi.org/10.1016/S0963-9969(00)00011-9

76. Volikakis, P., Biliaderis, C.G., Vamvakas, C., Zerfridis, G.K. (2004): Effects of a commercial oat- $\beta$-glucan concentrate on the chemical, physico-chemical and sensory attributes of low-fat white-brined cheese product. Food Research International 37, 83-94. https://doi.org/10.1016/j.foodres.2003.07.007

77. Wood, P.J. (2007): Cereal $\beta$-glucans in diet and health. Journal of Cereal Science 46, 230-238. https://doi.org/10.1016/j.jcs.2007.06.012

78. Xu, S.Y., Stanley, D.W., Goff, H.D., Davidson, V.J., LeMarguer, M. (1992): Hydrocolloid/milk gel formation and properties. Journal of Food Science 57, 96-102. https://doi.org/10.1111/j.1365-2621.1992.tb05433.x

79. Zare, F., Orsat, V. (2012): Microbial and physical properties of probiotic fermented milk supplemented with lentil flour. Journal of Food Research 1, 94-104. https://doi.org/10.5539/jfr.v1n1p94 